\title{
Growth, biomass, and energy quality of Acacia mangium timber grown at different spacings
}

\author{
Helio Tonini ${ }^{(1)}$, Dalton Roberto Schwengber ${ }^{(2)}$, Marina Moura Morales ${ }^{(3)}$, \\ Ciro Augusto de Souza Magalhães ${ }^{(4)}$ and Jane Maria Franco de Oliveira ${ }^{(2)}$
}

\begin{abstract}
(1)Embrapa Pecuária Sul, BR-153, Km 632,9, Vila Industrial, Zona Rural, Caixa Postal 242, CEP 96401-970 Bagé, RS, Brazil. E-mail: helio.tonini@embrapa.br (2)Embrapa Roraima, Rodovia BR-174, Km 8, Distrito Industrial, Caixa Postal 133, CEP 69301-970 Boa Vista, RR, Brazil. E-mail: dalton.schwengber@embrapa.br, jane.franco@embrapa.br ${ }^{(3)}$ Embrapa Florestas, Estrada da Ribeira, Km 111, Guaraituba, Caixa Postal 319, CEP 83411-000 Colombo, PR, Brazil. E-mail: marina.morales@embrapa.br (4)Embrapa Agrossilvipastoril, Rodovia dos Pioneiros, MT-222, Km 2,5, Zona Rural, Caixa Postal 343, CEP 78550-970 Sinop, MT, Brazil. E-mail: ciro.magalhaes@embrapa.br
\end{abstract}

\begin{abstract}
The objective of this work was to assess the effect of spacing on the growth, biomass allocation, and wood quality for energy purposes of Acacia magium. A randomized complete block design was carried out with three replicates and five treatments consisting of trees planted at different spacings: $2.0 \times 2.0,2.5 \times 2.5$, $3.0 \times 2.0,3.0 \times 2.5$, and $3.0 \times 3.0 \mathrm{~m}$. At 67 months after planting, the following species parameters were evaluated: performance (mortality, diameter growth, height, bark factor, and bark and biomass volume yield) and wood energy quality (basic density, higher-calorific value, ash, fixed carbon, and volatile materials) through the analysis of variance. Plant spacing did not affect volume and biomass production per hectare nor wood quality for energy purposes. The widest spacing $(3.0 \times 3.0 \mathrm{~m})$ provides better individual growth, and the narrowest one $(2.0 \times 2.0 \mathrm{~m})$ produces smaller trees, but with the highest percentage of dry biomass in the trunk, and can show the best energy potential at a rotation age from 40 to 50 months.

Index terms: Amazon, biomass accumulation, energy productivity, forest plantation, Roraima.

\section{Crescimento, biomassa e qualidade energética da madeira de Acacia mangium em diferentes espaçamentos}

\begin{abstract}
Resumo - O objetivo deste trabalho foi avaliar o efeito do espaçamento de plantio sobre o crescimento, a alocação de biomassa e a qualidade da madeira para geração de energia de Acacia magium. O experimento foi instalado em delineamento experimental de blocos ao acaso, com três repetições e cinco tratamentos que

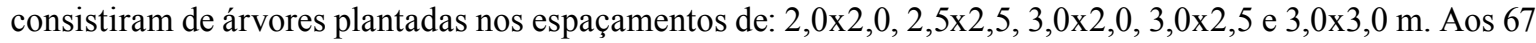
meses de plantio, avaliaram-se os seguintes parâmetros da espécie: desempenho (mortalidade, crescimento em diâmetro, altura, fator de casca, e produção volumétrica de casca e de biomassa) e qualidade energética da madeira (densidade básica, poder calorífico superior, cinzas, carbono fixo e materiais voláteis), por meio de análise de variância. $\mathrm{O}$ espaçamento de plantio não teve influência sobre a produção em volume e de biomassa por hectare, nem sobre a qualidade da madeira para a produção de energia. $\mathrm{O}$ maior espaçamento de plantio $(3,0 \times 3,0 \mathrm{~m})$ fornece maior crescimento individual, e o menor espaçamento $(2,0 \times 2,0 \mathrm{~m})$ produz árvores de menores dimensões, porém com maior percentagem de biomassa concentrada no tronco, e pode apresentar maior eficiência energética com a adoção de uma idade de rotação entre 40 a 50 meses.
\end{abstract}

Termos para indexação: Amazônia, acúmulo de biomassa, produção de energia, reflorestamento, Roraima.

\section{Introduction}

The main application traditionally given to wood around the world is combustion for energy production due to its high-productive and renewable potential. Wood combustion accounts for more than half of the forest biomass consumed worldwide, mainly in developing countries, such as Brazil (Moreira, 2011), which is the largest charcoal producer in the world (Protásio et al., 2014). In Brazil, the increase of areas planted with "energy forestry" makes its energy matrix environmentally healthier due to the replacement of fossil fuels by renewable energy sources; moreover, this matrix is socially fair because of the large number of job positions generated by investments in the sector (Moreira, 2011). However, it is necessary to intensify the research on the topic, and to develop technologies to help selecting the most suitable species and strains for different planting regions, in order to increase the wood combustion (forest biomass) potential for 
power generation in the country. Besides, it is worth developing deployment, management, and harvesting systems, as well as more efficient end-use processes (Soares et al., 2006).

Tree spacing in silviculture is of great relevance to set the amount of natural resources available, as it influences the plant growth rates, rotation age, wood quality, and production costs (Eloy et al., 2014). Despite their importance, studies addressing tree spacing effects on the production and wood quality, for power generation purposes, remain scarce and focused on the genus Eucalyptus (Dinardi, 2014; Eloy et al., 2014; Sereghetti et al., 2015). Only Vale et al. (2000) assessed the effect of silvicultural practices (fertilization), without spacing variation, on the wood of Acacia mangium trees grown for power generation purposes.

Acacia mangium Willd is acknowledged for its timber production potential, atmospheric carbon removal, and soil storage, since it grows fast even in degraded soils (Vélez \& Del Valle, 2007), at pure or mixed stands (Nouvellon et al., 2012; Santos et al., 2016). The species is capable of adapting to Brazilian edaphic and climatic conditions (Souza et al., 2004; Laclau et al., 2008); besides, it shows low-nutrient requirements, high-nutrient efficiency, acidity, and tolerance to soil compaction (Pegoraro et al., 2014). However, little advancement on silviculture knowledge has been recorded, mainly when it comes to the interaction among spacing, fertilization, productivity, and wood quality.

Commercial A. mangium (which is the main planted forest species) plantations in Roraima were launched in 1999, and the planted area covered approximately 27 thousand hectares. The species shows a great potential for plantation, mainly in sandy soils, which are not suitable for agricultural production. However, it is worth having more investments in the genetic enhancement and in the development of silvicultural practices adapted to local conditions, as well as in wood processing technology. The species is a future alternative for reforestation conducted for lumber, cellulose, and power generation. However, in order to reach such a goal, it is necessary to develop researches focused on improving the production system, so that the species can reach its true potential.

The objective of this work was to assess the effect of spacing on the growth, biomass allocation, and wood quality of Acacia magium for energy generation purposes.

\section{Materials and Methods}

The study was carried out in São Joaquim farm $\left(2^{\circ} 56^{\prime} 50^{\prime \prime} \mathrm{N}, 60^{\circ} 20^{\prime} 29^{\prime \prime} \mathrm{W}\right.$, at $111 \mathrm{~m}$ altitude), which belongs to the company FIT Manejo Florestal Ltda., Serra-da-Lua region, in the municipality of Cantá, in the state of Roraima, Brazil.

The region is covered by a forest-savanna transition vegetation, and its climate is classified as Ami, according to the classification of Köppen-Geiger. The region has monsoon characteristics, with six months of heavy rainfall, with $1,453 \mathrm{~mm}$, from April to September, and six months of light rainfall, with $298 \mathrm{~mm}$ mean rainfall, from October to March (Projeto Radambrasil, 1975). The mean temperature ranges from 26 to $29^{\circ} \mathrm{C}$. Xanthic Hapludult (Argissolo Amarelo distrófico), which is deep and well drained, prevails in the region; this soil class has approximately $11 \%$ clay content in the A horizon, and $28 \%$ in the B horizon, and shows an abrupt, textural change (Vale Júnior \& Schaefer, 2010). Soil chemical characteristics were determined according to Donagema et al. (2011) (Table 1).

The experiment was implemented in June, 2010, in a randomized complete block design, with three replicates, and five treatments which consisted of trees planted at different spacing: T1, 2.0x2.0 m; T2, 2.5x2.5 $\mathrm{m}$; T3, 3.0x2.0 m; T4, 3.0x2.5 m; and T5, 3.0x3.0 m, in experimental units of $40 \times 50 \mathrm{~m}$, in 3.0 ha experimental area (Figure 1).

The entire experimental area was treated with 1.0 $\mathrm{Mg} \mathrm{ha}{ }^{-1}$ dolomitic limestone, in December, 2009. Limestone was incorporated to the soil surface with the aid of a harrowing grid. Scarification was carried out at $80.0 \mathrm{~cm}$ soil depth, in order to prepare the soil. Fertilization was applied at $60-90-60 \mathrm{~kg} \mathrm{ha}^{-1} \mathrm{~N}_{-} \mathrm{P}_{2} \mathrm{O}_{5^{-}}$ $\mathrm{K}_{2} \mathrm{O}$, in addition to $24.0 \mathrm{~kg} \mathrm{ha}^{-1} \mathrm{~S}, 2.0 \mathrm{~kg} \mathrm{ha}^{-1} \mathrm{~B}$, and $2.5 \mathrm{~kg} \mathrm{ha}^{-1} \mathrm{Zn}$. The amount of fertilizer was set per unit area, and the doses per plant changed depending on the population density, in order to keep uniformity. The following substances were used as fertilization source: ammonium sulfate $(18 \% \mathrm{~N}, 24 \% \mathrm{~S})$, urea $(45 \% \mathrm{~N})$, triple superphosphate $\left(37 \% \mathrm{P}_{2} \mathrm{O}_{5}\right)$, potassium chloride $\left(60 \% \mathrm{~K}_{2} \mathrm{O}\right)$ and FTE-BR 12 (fritted trace elements, $9 \%$ $\mathrm{Zn}$, and $1.8 \% \mathrm{~B})$. Ammonium sulfate $(18 \% \mathrm{~N}, 24 \% \mathrm{~S})$ 
was applied 30 days after planting. One Half of the used urea $(45 \% \mathrm{~N})$ was applied at the end of the rainy season, and the other half, at the beginning of the following rainy season. Triple superphosphate $(37 \%$ $\mathrm{P}_{2} \mathrm{O}_{5}$ ) mixed with filling soil was applied to the pit, immediately after liming. Potassium chloride $(60 \%$ $\mathrm{K}_{2} \mathrm{O}$ ) was applied in three equal parts. FTE-BR 12, which was used as $\mathrm{Zn}$ and $\mathrm{B}$ source, was applied to the pit in two equal parts: together with phosphorus potassium and boric acid (17\% B), at the end of the rainy season (in the first half of August), and together with the urea- $\mathrm{KCl}$ mixture, at the beginning of the following rainy season (in May). The first potassium chloride $\left(60 \% \mathrm{~K}_{2} \mathrm{O}\right)$ part, mixed with $\mathrm{P}$, was applied to the planting pit; its second part, mixed with $\mathrm{N}$, was

Table 1. Chemical soil analysis in the experimental area.

\begin{tabular}{lcc}
\hline Attribute & \multicolumn{2}{c}{ Soil layer } \\
\cline { 2 - 3 } & $0-20 \mathrm{~cm}$ & $60-80 \mathrm{~cm}$ \\
\hline $\mathrm{pH} \mathrm{H} \mathrm{H}_{2} \mathrm{O}$ & 5.5 & 4.7 \\
$\mathrm{P}(\mathrm{mg} \mathrm{dm}$ & -3 & 1.0 \\
$\mathrm{~K}\left(\mathrm{mg} \mathrm{dm}^{-3}\right)$ & 2.1 & 8.0 \\
$\mathrm{Ca}\left(\mathrm{cmol}_{\mathrm{c}} \mathrm{dm}^{-3}\right)$ & 11.0 & 0.17 \\
$\mathrm{Mg}\left(\mathrm{cmol}_{\mathrm{c}} \mathrm{dm}^{-3}\right)$ & 0.32 & 0.05 \\
$\mathrm{Al}\left(\mathrm{cmol}_{\mathrm{c}} \mathrm{dm}^{-3}\right)$ & 0.10 & 0.19 \\
$\mathrm{H}+\mathrm{Al}\left(\mathrm{cmol}_{\mathrm{c}} \mathrm{dm}^{-3}\right)$ & 0.17 & 1.37 \\
$\mathrm{Base}$ saturation $(\%)$ & 1.41 & 15.0 \\
Al saturation $(\mathrm{m}, \%)$ & 24.0 & 45.0 \\
\hline
\end{tabular}

applied at the end of the rainy season (in the first half of August); and the third part, mixed with N, was applied at the beginning of the following rainy season.

Multiple trunks were removed six months after planting, and it enabled stem formation and helped controlling tree number (stems) variations per hectare.

A diameter tape was used to measure the diameter at breast height $(\mathrm{DBH})$ in plants located in the central rows of each experimental unit; the two lateral tree lines were disregarded. The height of the first 50 plants was measured by an electronic hypsometer; the measurements were performed at 14, 29, 43, and 67 months after planting.

Tree samples showing medium DBH, at the age 67 months, were selected and cut for biomass and wood quality analysis, according to Sereghetti et al. (2015); and one tree was selected per treatment and block, thus totaling 15 sample trees.

The fresh and dry masses of all tree-biomass components such as leaves, dead and living branches -thin or thick $(\leq 2.5 \mathrm{~cm}$ diameter $)$-, trunk bark, fruit, and flowers were determined. Dry weight was measured by collecting a sample from each biomass component per tree, and by storing it in greenhouse at $60^{\circ} \mathrm{C}$ to dry until reaching constant weight.

Wood discs (approximately $2.5 \mathrm{~cm}$ thick) were cut from the trunk base, and from $25,50,75$, and $90 \%$ of the total trunk height, in order to find the basic density. The mean basic density per tree was determined

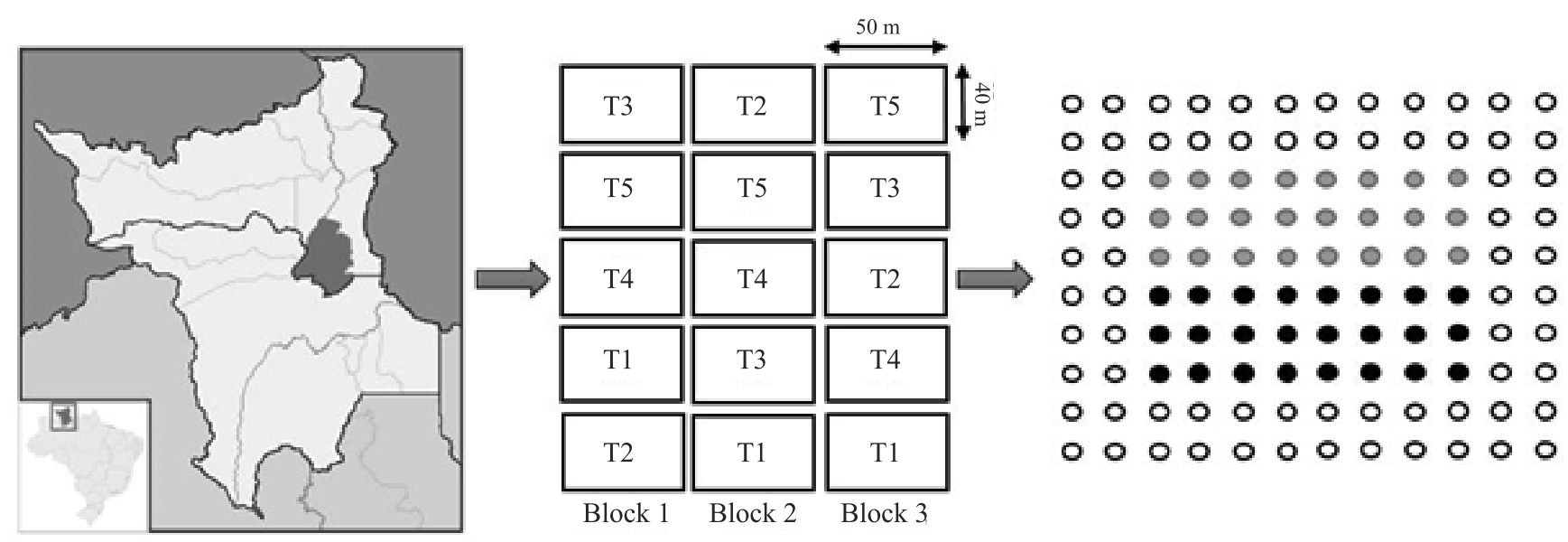

Figure 1. Location and experiment sketch with blocks, randomized treatments, border trees (unfilled circles), trees showing the diameter at breast height (DBH) and height measurements (dark circles), and trees showing DAP measurements only

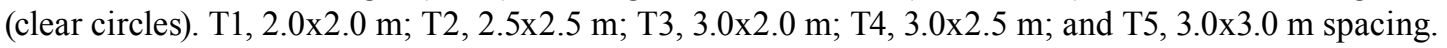


according to recommendations by Associação Brasileira de Normas Técnicas (2003), and trunk biomass was determined by the following equation:

$$
\text { Trunk biomass }(\mathrm{kg})=\sum \mathrm{V}_{\mathrm{i}} \times \mathrm{d}_{\mathrm{i}}
$$

in which: $\mathrm{V}_{\mathrm{i}}$ is the trunk volume in section $\mathrm{i}\left(\mathrm{m}^{3}\right)$; and $\mathrm{d}_{\mathrm{i}}$ is the wood density in section $\mathrm{i}\left(\mathrm{kg} \mathrm{m}^{-3}\right)$.

The bark factor was found through the trunk diameter ratio - with, or without bark -, resulting from the sum of trunk diameters measured in the wood discs (Husch et al., 1982), as follows:

$$
\mathrm{k}=\sum \mathrm{Dsc} / \sum \mathrm{Dcc}
$$

in which: Dsc is the diameter without bark; Dec is the diameter with bark.

The individual trunk volume was found by accurately measuring the wood volume in the trees at 0.10, 0.7, and $1.30 \mathrm{~m}$ above the ground, and at every meter from the last position up to the total height (Pedrosa et al., 2013), according to the Smalian method. The volume per hectare, in trees at 67 months of age, was estimated by multiplying the mean individual volume by the estimated number of trees per hectare, and by subtracting the result of such multiplication from the mortality accumulated over the assessed period.

The higher calorific value (HCV) and immediate analyses were conducted in wood discs collected at $\mathrm{BH}$, according to recommendations by Associação Brasileira de Normas Técnicas (1984, 1986). Data concerning the higher calorific value, trunk biomass, and planting density were used to calculate the energy potential, in tonne of oil equivalent per hectare, by $\mathrm{EP}=\left[\left((\mathrm{HCV} / 10000) \times\left(\mathrm{B}_{\mathrm{T}}\right)\right) / 1\right] \times(\mathrm{TD})$, in which: $\mathrm{EP}$ is the energy potential (toe $\mathrm{ha}^{-1}$ ); $\mathrm{HCV}$ is the higher-calorific wood value, or trunk biomass value $\left(\mathrm{kcal} \mathrm{kg}^{-1}\right) ; 10,000$ is the fuel higher calorific value $\left(\mathrm{kcal} \mathrm{kg}^{-1}\right)$; $\mathrm{B}_{\mathrm{T}}$ is the individual trunk biomass on a dry basis ( $\mathrm{kg}$ per tree); 1 is the ratio between wood weight ( $t$ ) and energy (toe); TD is the tree density (trees ha ${ }^{-1}$ ).

Data were compared by the analysis of variance, and the Tukey's test, at 5\% probability.

\section{Results and Discussion}

There was no significant mortality difference between spacing $(\mathrm{F}=1.56, \mathrm{p}=0.273)$ in trees at the age of 67 months. Mortality varied between 12.6 and $20.7 \%$ (Table 2), and it was within the range (4 to $53 \%$ ) recorded for $A$. mangium plantations in different regions of the globe (Kamo et al., 2009; Tonini et al., 2010; Nirsatmanto, 2016). The species mortality rate in Brazil, both in trials and in commercial plantations (age group from 2.0 to 5.3 years, and vital space between 2.25 and $16 \mathrm{~m}^{2}$ ) varied from 0 and $30 \%$ (Souza et al., 2004; Tonini, 2010). These variations are likely to occur because the species is cultivated in a wide variety of sites, such as in areas showing good fertility and high-rainfall rates, as well as in soils degraded by mining activities; consequently, its performance changes from region to region.

Species mortality rates tended to increase mainly in trees aged 43 months, or in older ones, and they were higher in T1 (Figure 2). This result partially

Table 2. Treatments, vital space, initial density, and accumulated mortality in Acacia mangium trees at 67 months after planting.

\begin{tabular}{lcccc}
\hline Treatment & $\begin{array}{c}\text { Spacing } \\
(\mathrm{m})\end{array}$ & $\begin{array}{c}\text { Vital space } \\
\left(\mathrm{m}^{2}\right)\end{array}$ & $\begin{array}{c}\text { Initial density } \\
\left(\text { tree ha }^{-1}\right)\end{array}$ & $\begin{array}{c}\text { Mortality } \\
(\%)\end{array}$ \\
\hline 1 & $2.0 \times 2.0$ & 4.0 & 2,500 & 20.7 \\
2 & $2.5 \times 2.5$ & 6.25 & 1,600 & 14.5 \\
3 & $3.0 \times 2.0$ & 6.0 & 1,667 & 11.5 \\
4 & $3.0 \times 2.5$ & 7.5 & 1,333 & 12.6 \\
5 & $3.0 \times 3.0$ & 9.0 & 1,111 & 16.8 \\
\hline
\end{tabular}

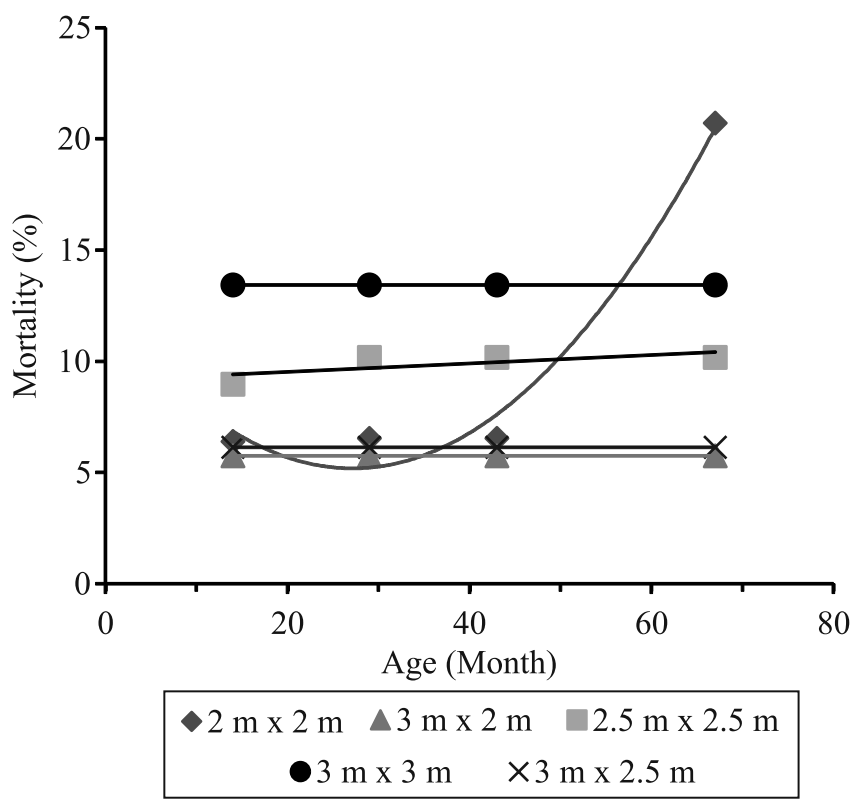

Figure 2. Accumulated mortality in different Acacia mangium spacings, in the municipality of Cantá, in the state of Roraima, Brazil. 
corroborates the study by Kurinobu et al. (2006), who state that the A. mangium mortality rate, in nonthinned plantations, rapidly increases after five years.

The parameter "growth" just showed statistical difference for trunk diameter $(\mathrm{F}=13.022, \mathrm{p}=0.001)$ in trees belonging to $\mathrm{T} 1$ (the lowest spacing). The lowest $\mathrm{DBH}$ was found in $\mathrm{T} 1$, and the highest one, in $\mathrm{T} 5$ (Table 3).

A strong influence of increased spacing on diameter growth was expected to be recorded in studies conducted in Brazil, involving introduced and native species such as Pinus taeda (Lima, 2014), Eucalyptus grandis $\mathrm{x}$ Eucalyptus urophylla clones (Dinardi, 2014), Acacia mearnsii, Mimosa scabrella, and Ateleia glazioveana (Eloy et al., 2014). However, different intermediate spacing does not often statistically differ from each other, as they show the same growth trend, similarly to results found in the current study (Figure $3 \mathrm{~A}$ ).

The effect of spacing on height is controversial, and changes depend on species, genetic material, age, and density. Nirsatmanto (2016) applied different spacing (3.0x3.0 m and $2.0 \times 2.0 \mathrm{~m})$ to A. mangium strains, in Java, and found that trees got taller in narrower spacing, as well as that the result can change depending on the genetic material. Trees in the current study showed a close mean height at all assessed ages and spacing (Figure $3 \mathrm{~B}$ ).

The mean annual volume increment (MAI) ranged from 23.15 to $25.88 \mathrm{~m}^{3} \mathrm{ha}^{-1}$, at the age of 67 months. This range is low, if one compares it to the species performance reported for the best sites, where MAI

Table 3. Means of the dendrometric variables of Acacia mangium trees, at different spacing, at 67 months after planting in the municipality of Cantá, in the state of Roraima, Brazil.

\begin{tabular}{|c|c|c|c|c|c|c|c|c|}
\hline Treatment & Spacing $(\mathrm{m})$ & $\mathrm{DBH}(\mathrm{cm})$ & $\mathrm{MAI}_{\mathrm{d}}(\mathrm{cm})$ & Total height (m) & $\mathrm{MAI}_{\mathrm{h}}(\mathrm{m})$ & $\mathrm{V}\left(\mathrm{m}^{3} \mathrm{ha}^{-1}\right)$ & $\mathrm{MAI}_{\mathrm{V}}\left(\mathrm{m}^{3}\right)$ & $\mathrm{K}$ \\
\hline 1 & $2.0 \times 2.0$ & $9.6 \mathrm{c}$ & 1.71 & 11.5 & 2.05 & 144.5 & 25.88 & 0.91 \\
\hline 2 & $2.5 \times 2.5$ & $11.6 \mathrm{~b}$ & 2.07 & 11.8 & 2.11 & 136.7 & 24.48 & 0.91 \\
\hline 3 & $3.0 \times 2.0$ & $11.4 \mathrm{~b}$ & 2.04 & 12.0 & 2.14 & 153.5 & 27.49 & 0.90 \\
\hline 4 & $3.0 \times 2.5$ & $11.9 \mathrm{ab}$ & 2.13 & 11.9 & 2.13 & 134.1 & 24.01 & 0.91 \\
\hline 5 & $3.0 \times 3.0$ & $13.3 \mathrm{a}$ & 2.38 & 11.5 & 2.06 & 129.3 & 23.15 & 0.90 \\
\hline
\end{tabular}

$\mathrm{DBH}$, diameter at breast height; $\mathrm{MAI}_{\mathrm{d}}$, mean annual diameter increase; $\mathrm{MAI}_{\mathrm{h}}$, mean annual height increase; $\mathrm{V}$, total volume per hectare; $\mathrm{MAI}_{\mathrm{v}}$, mean annual volume increase; K, bark factor. Means followed by equal letters do not differ from each other, by Tukey's test, at $5 \%$ probability.
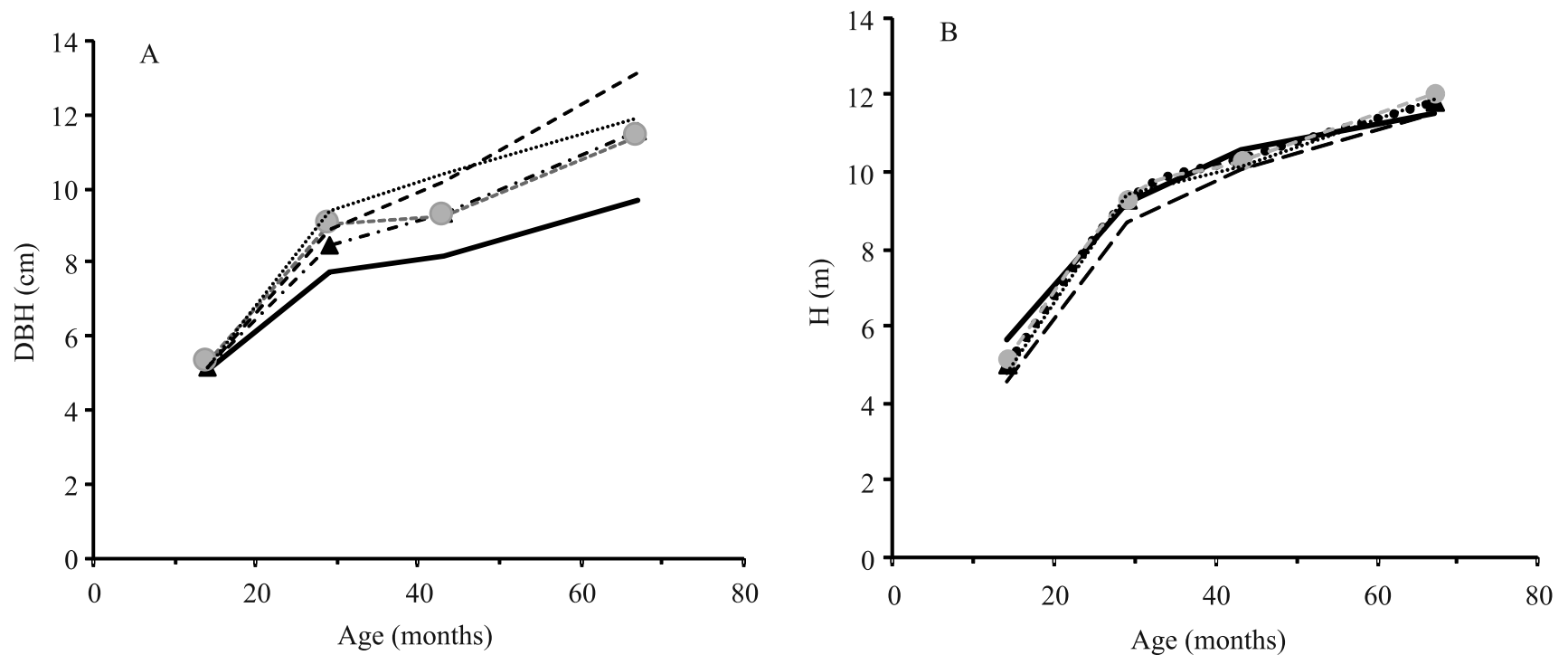

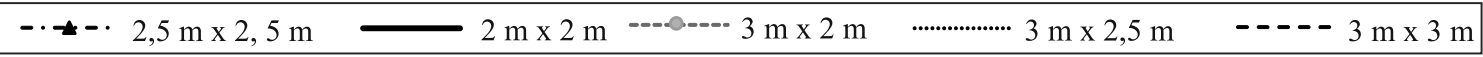

Figure 3. Diameter at breast height (A) and height (B), in Acacia mangium trees at different spacings in the municipality of Cantá, in the state of Roraima, Brazil. 
ranged from 35 to $45 \mathrm{~m}^{3} \mathrm{ha}^{-1}$ per year (Vélez \& Del Valle, 2007).

The rainfall regime, mainly during dry season, which influences water availability in the soil (toughness), has a strong impact on the productivity, biomass accumulation, and partitioning of $A$. mangium (Bastien-Henri et al., 2010; Hung et al., 2016). Dry periods longer than two months, as well as prolonged dry seasons equal to or longer than six months, lead to a growth-rate reduction, and may limit the commercial cultivation of this species (Mead \& Miller, 1991). Such fact seems to be the main limiting one to the species productivity in Roraima state.

A higher-volume production per unit area would be expected in the narrowest spacing; however, it did not happen in the current study due to the diameter growth decline after 20 months, as well as to the rapid mortality increase after the age of 43 months in 2.0x2.0 $\mathrm{m}$ spacing (Figure $3 \mathrm{~A}$ ). According to Nirsatmanto (2016), the diameter growth rapidly declined in unthinned $A$. mangium plantations because of the competition between individuals, which may lead to a significant reduction of volume yield .

The bark factor, which has been referred to as a mineral translocator for charcoal, was not influenced by spacing ( $\mathrm{f}=0.847 ; \mathrm{p}=0.533$ ). Despite accounting for 10 to $15 \%$ of the tree total volume, the bark factor is treated as an undesirable portion (Vital et al., 1989).

Spacing had a significant effect on total individual biomass production $(\mathrm{f}=9.26, \mathrm{p}=0.04)$, as well as on trunk ( $\mathrm{f}=4.51, \mathrm{p}=0.04)$ and crown $(\mathrm{f}=4.16$, $\mathrm{p}=0.04$ ) biomass production. Only biomass of dead thin branches, among the biomass components in the crown, varied significantly $(f=4.74, p=0.029)$ between treatments (Table 4). Although the estimated biomass production per unit area was not significant, it ranged from 45.6 to $60.4 \mathrm{Mg} \mathrm{ha}^{-1}$, that is, there was a difference of $14.8 \mathrm{Mg} \mathrm{ha}^{-1}$ between the shortest and the longest spacing assessed in the current study. Such production was higher than that found by Costa et al. (2015), in Iranduba, AM, Brazil, who recorded 33.4 $\mathrm{Mg} \mathrm{ha}^{-1}$ biomass production for trees aged 108 months, at $3.0 \times 2.0 \mathrm{~m}$ spacing. Santos et al. (2016) found 44.5 $\mathrm{Mg} \mathrm{ha}^{-1}$ for trees at the age of 60 months in Seropédica, RJ, Brazil, at $3.0 \times 3.0 \mathrm{~m}$ spacing.

Trees grown at wider spacings $(3.0 \times 2.5$ and $3.0 \times 3.0 \mathrm{~m})$ produced the highest-total individual biomass, which varied between $29.9(2.0 \times 2.0 \mathrm{~m})$ and $58.4(3.0 \times 3.0 \mathrm{~m}) \mathrm{kg}$ per tree. The increased spacing adopted in the extreme treatments promoted biomass accumulation differences of trunk and crown in $2.0 \times 2.0 \mathrm{~m}$ and $3.0 \times 3.0 \mathrm{~m}$ spacing, only. However, the best crown development reduced the biomass proportion from $59.0 \%(3.0 \times 2.5 \mathrm{~m})$ to $71.2 \%$ $(2.0 \times 2.0 \mathrm{~m})$ allocated to the stem in longer spacing (Figure $4 \mathrm{~A}$ ). The narrowest spacing resulted in greater biomass allocation to dead and thin branches, whereas wider spacings resulted in the best biomass allocation to living thick branches (Figure $4 \mathrm{~B}$ ).

Individual biomass accumulation gains in the trunk due to spacing reduction are expected and commercially desirable; however, the magnitude of such gains depends on species, site, available area, and planting age. The mean individual biomass production in the trunk (26.4 $\mathrm{kg}$ per tree), recorded in the current study, was higher than that found by Vale et al. (2000), in Botucatu, SP, Brazil, who recorded $19.8 \mathrm{~kg}$ per tree at the age of 84 months, at $3.0 \times 2.0 \mathrm{~m}$ spacing.

Table 4. Mean of biomass components in Acacia mangium trees, according to spacing, at the age of 67 months, after planting, in the municipality of Cantá, in the state of Roraima, Brazil.

\begin{tabular}{|c|c|c|c|c|c|c|c|c|c|c|c|c|}
\hline Treatment & $\begin{array}{c}\text { Spacing } \\
\text { (m) }\end{array}$ & $\begin{array}{c}\mathrm{B}_{\text {total }} \\
\left(\mathrm{Mg} \mathrm{ha}^{-1}\right)\end{array}$ & $\begin{array}{l}B_{\text {ind }} \\
------ \\
\end{array}$ & $\mathrm{B}_{\mathrm{T}}$ & $\mathrm{B}_{\mathrm{C}}$ & L & $\begin{array}{c}\text { LTB } \\
----(k \\
\end{array}$ & $\begin{array}{l}\text { DTB } \\
\text { tree)-- }\end{array}$ & LThB & DThB & DF & $\begin{array}{c}\text { UF } \\
--- \\
\end{array}$ \\
\hline 1 & $2.0 \times 2.0$ & 60.4 & $29.9 b$ & $21.3 b$ & $8.6 b$ & 1.2 & 2.6 & $3.2 \mathrm{~b}$ & 2.5 & 1.5 & 0.02 & 0.04 \\
\hline 2 & $2.5 \times 2.5$ & 52.8 & $39.7 \mathrm{ab}$ & $27.2 \mathrm{ab}$ & $12.5 \mathrm{ab}$ & 1.2 & 3.3 & $4.4 \mathrm{ab}$ & 6.2 & 3.3 & 0.00 & 0.02 \\
\hline 3 & $3.0 \times 2.0$ & 51.1 & $38.0 \mathrm{~b}$ & $26.4 \mathrm{ab}$ & $11.6 \mathrm{ab}$ & 1.4 & 2.7 & $4.5 \mathrm{ab}$ & 3.7 & 2.2 & 0.00 & 0.01 \\
\hline 4 & $3.0 \times 2.5$ & 45.6 & 41.1ab & $24.2 \mathrm{ab}$ & $16.8 \mathrm{ab}$ & 1.5 & 3.9 & $5.6 \mathrm{a}$ & 7.1 & 4.1 & 0.07 & 0.04 \\
\hline 5 & $3.0 \times 3.0$ & 54.4 & $58.4 \mathrm{a}$ & $39.4 \mathrm{a}$ & $18.9 \mathrm{a}$ & 2.3 & 4.7 & $5.4 \mathrm{a}$ & 10.4 & 5.8 & 0.10 & 0.14 \\
\hline
\end{tabular}

$\mathrm{B}_{\text {total }}$, total biomass per hectare; $\mathrm{B}_{\text {indv }}$, total individual biomass; $\mathrm{B}_{\mathrm{T}}$, individual biomass of the trunk; $\mathrm{B}_{\mathrm{c}}$, individual biomass of the crown; $\mathrm{L}$, individual biomass of the leaves; LTB, individual biomass of living thin branches; DTB, individual biomass of dead thin branches; LThB, individual biomass of live thick branches; DThB, individual biomass of dead thick branches; DF, individual biomass of dry fruit; UF, individual biomass of unripe fruit. Means followed by equal letters did not differ, by Tukey's test, at 5\% probability. 
The amount of total biomass proportion allocated to the trunk showed low variation between treatments $(4.3 \%)$ in the current study, in comparison to that recorded in studies of similar nature. Eloy et al. (2014) compared vital spaces from 2.0 to $4.5 \mathrm{~m}^{2}$, in 5-yearold trees, and found $9.2 \%$ biomass accumulation gain in the trunk of Acacia mearnsii; 15.6\%, in Mimosa scabrella; $11.35 \%$, in Ateleia glazioveana, and $3.9 \%$ in Eucalyptus grandis. However, Lima (2014) found 58\% biomass accumulation gain in the trunk of 108-monthold Pinus taeda trees, in vital spaces from $12-16 \mathrm{~m}^{2}$ to 1-4 $\mathrm{m}^{2}$. There was no significant difference between spacing variations and wood energy characteristics (Table 5). Basic density ranged from 0.56 to $0.61 \mathrm{~g}$ $\mathrm{cm}^{-3}$ and was not significantly influenced by planting spacing ( $\mathrm{f}=0.847, \mathrm{p}=0.533)$. These basic density values were within the range recorded for the species ( 0.45 to $0.69 \mathrm{~g} \mathrm{~cm}^{-3}$ ) in Asian commercial plantations (Krisnawati et al., 2011), and higher than those so far recorded ( 0.52 to $0.54 \mathrm{~g} \mathrm{~cm}^{-3}$ ) for 84 and 108-monthold plantations in Brazil (Vale et al., 1999; Costa et al., 2015).

According to Vale et al. (2000) and Costa et al. (2015), HCV ranged from 4,619 kcal kg-1 to 4,377 kcal kg-1 in 84 and 108-month-old trees, respectively, when they were subjected to the same planting spacing $(3.0 \times 2.0 \mathrm{~m})$. These values are close to those found for this spacing in the current study $\left(4,419.79 \mathrm{kcal} \mathrm{kg}^{-1}\right)$, as

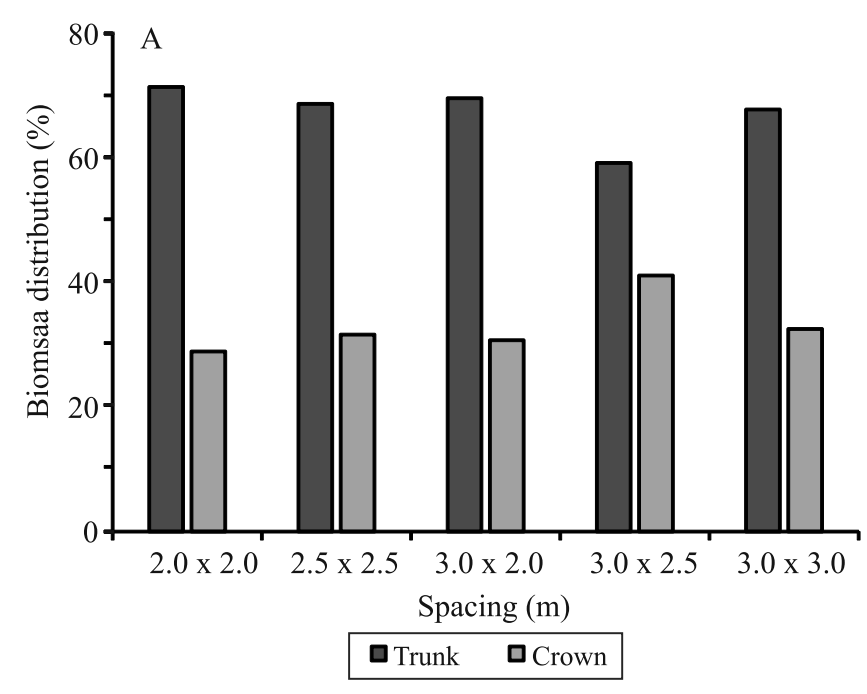

well as close to the results reported by Quirino (2005), for genera such as Eucalyptus $\left(4,696 \mathrm{kcal} \mathrm{kg}^{-1}\right)$, Acacia decurrens $\left(4,550 \mathrm{kcal} \mathrm{\textrm {kg } ^ { - 1 } )}\right.$ and Acacia polyphyla $\left(4,760 \mathrm{kcal} \mathrm{kg}^{-1}\right)$.

The energy potential was not significantly influenced $(\mathrm{F}=4.10, \mathrm{p}=0.112)$ by spacing for trees at 67 months of age (Figure 5). However, mortality data suggested that the $2.0 \times 2.0 \mathrm{~m}$ spacing could improve the energy potential through the adoption of rotation age from 40 to 50 months.

Information on biomass productivity and allocation in plants should help making the decision about the best initial spacing to be adopted, since the quality of the wood for power generation purposes was not influenced by spacing. The smallest spacing led to shorter trees, although these trees showed the highest percentage for dry biomass in the trunk. The estimated biomass production gain in the trunks was $14.8 \mathrm{Mg}$ $\mathrm{ha}^{-1}$, based on a comparison between the narrowest and widest spacings. A higher-biomass production in the trunks is a desirable quality characteristic linked to lower-water and lower-ash contents, as well as to higher-basic density and sustainability resulting from decreased nutrient recruitment. The removal of branches and leaves in short-rotation plantations, in Sumatra, reduced the volume yield by $21 \%$ in A. mangium plantations (Hardiyanto \& Nambiar, 2014).

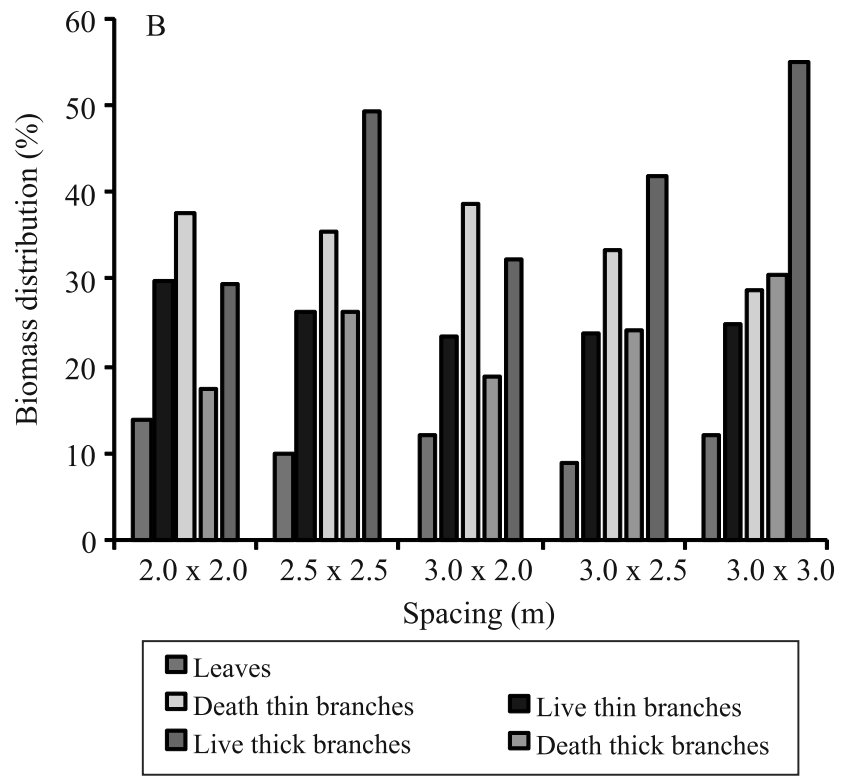

Figure 4. Biomass distribution in the trees (A) and in the crown (B), according to planting spacing, in the municipality of Cantá, in the state of Roraima, Brazil. 
Table 5. Energy characteristics of Acacia mangium wood at different spacing, in the municipality of Cantá, in the state of Roraima, Brazil.

\begin{tabular}{lccccc}
\hline Treatment & $\begin{array}{c}\mathrm{D}_{\mathrm{b}} \\
\left(\mathrm{g} \mathrm{cm}^{-3}\right)\end{array}$ & $\begin{array}{c}\mathrm{VM} \\
(\%)\end{array}$ & $\begin{array}{c}\text { Ashes } \\
(\%)\end{array}$ & $\begin{array}{c}\mathrm{FC} \\
(\%)\end{array}$ & $\begin{array}{c}\mathrm{HCV} \\
\left(\mathrm{kcal} \mathrm{kg}^{-1}\right)\end{array}$ \\
\hline 1 & 0.59 & 82.02 & 0.38 & 17.58 & $4,419.73$ \\
2 & 0.56 & 82.54 & 0.50 & 16.95 & $4,934.90$ \\
3 & 0.57 & 82.29 & 0.4 & 17.25 & $4,419.79$ \\
4 & 0.61 & 82.18 & 0.45 & 17.36 & $4,445.90$ \\
5 & 0.56 & 80.86 & 0.63 & 18.50 & $4,502.98$ \\
\hline
\end{tabular}

$\mathrm{D}_{\mathrm{b}}$, basic density; $\mathrm{VM}$, volatile materials; FC, fixed carbon; HCV, higher calorific value.

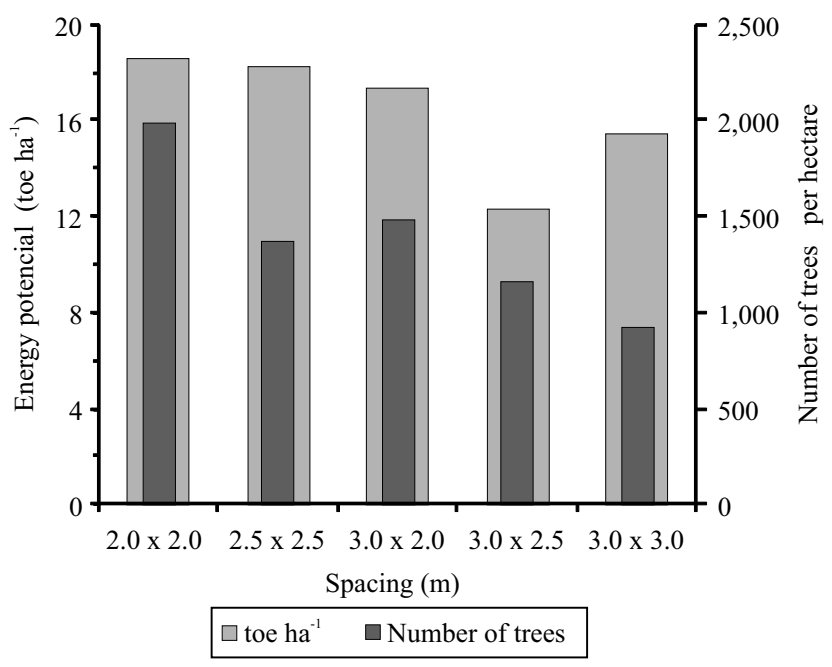

Figure 5. Energy performance of Acacia mangium wood at different spacings, in the municipality of Cantá, in the state of Roraima, Brazil.

\section{Conclusions}

1. Planting spacing has no effect on trunk volume, on total biomass, and on the quality of the wood of Acacia mangium for energy purposes.

2. Planting spacing significantly influences the trunk diameter increment and biomass allocation in the plant; and a wider spacing of $3.0 \times 3.0 \mathrm{~m}$ provides a higher-diameter growth, individual volume, and individual biomass production.

3. The narrowest spacing is considered advantageous for energy purposes due to the lower-individual biomass accumulation in the crown; a better power generation potential can be attained at a reduced spacing of $2.0 \times 2.0 \mathrm{~m}$, by adopting a rotation age from 40 to 50 months.

\section{Acknowledgments}

To FIT Manejo Florestal Ltda., for the support.

\section{References}

ASSOCIAÇÃO BRASILEIRA DE NORMAS TÉCNICAS. NBR 11941: Determinação da densidade básica em madeira. Rio de Janeiro, 2003. 6p.

ASSOCIAÇÃO BRASILEIRA DE NORMAS TÉCNICAS. NBR 8633: carvão vegetal: determinação do poder calorífico: método de ensaio. Rio de Janeiro, 1984. 13p.

ASSOCIAÇÃO BRASILEIRA DE NORMAS TÉCNICAS. NBR 8112 Carvão vegetal: análise imediata: método de ensaio. Rio de Janeiro, 1986. 5p.

BASTIEN-HENRI, S.; PARK, A.; ASHTON, M.; MESSIER, C. Biomass distribution among tropical tree species grown under differing regional climates. Forest Ecology and Management, v.260, p.403-410, 2010. DOI: 10.1016/j.foreco.2010.04.035.

COSTA, K.C.P. da; LIMA, R.M.B. de; FERREIRA, M.J. Biomass and energy yield of leguminous tress cultivated in Amazonas. Floresta, v.45, p.705-712, 2015. DOI: 10.5380/rf.v45i4.36749.

DINARDI, A.J. Viabilidade técnica e econômica de povoamentos de Eucalyptus spp. sob diferentes espaçamentos visando a produção de biomassa para energia. 2014. 91p. Tese (Doutorado) - Universidade Estadual Paulista Julio de Mesquita Filho, Botucatu.

DONAGEMA, G.K.; CAMPOS, D.V.B. de; CALDERANO, S.B. TEIXEIRA, W.G.; VIANA, J.H.M (Org.). Manual de métodos de análise de solos. 2.ed. rev. Rio de Janeiro: Embrapa Solos, 2011. 230p. (Embrapa Solos. Documentos, 132).

ELOY, E.; CARON, B.O.; SILVA, D.A. da; SCHMIDT, D.; TREVISAN, R.; BEHLING, A.; ELLI, E.F. Influência do espaçamento nas características energéticas de espécies arbóreas em plantios de curta rotação. Revista Árvore, v.38, p.551-559, 2014. DOI: $10.1590 / \mathrm{S} 0100-67622014000300018$.

HARDIYANTO, E.B.; NAMBIAR, E.K.S. Productivity of successive rotations of Acacia mangium plantations in Sumatra, Indonesia: impacts of harvest and inter-rotation site management. New Forests, v.45, p.557-575, 2014. DOI: 10.1007/s11056-0149418-8.

HUNG, T.T.; ALMEIDA, A.C.; EYLES, A.; MOHAMMED, C. Predicting productivity of Acacia hybrid plantations for a range of climates and soils in Vietnam. Forest Ecology and Management, v.367, p.97-111, 2016. DOI: 10.1016/j.foreco.2016.02.030.

HUSCH, B.; MILLER, C.I.; BEERS, T.W. Forest mensuration. $3^{\text {rd }}$ ed. New York: J. Willey \& Sons, 1982. 397p.

KAMO, K.; VACHARANGKURA, T.; TIYAMON, S.; VIRIYABUNCHA, C.; THAINGAM, R.; SAKAI, M. Response of unmanaged Acacia mangium plantations to delayed thinning in North-East Thailand. Journal of Tropical Forest Science, v.21, p.223-234, 2009 . 
KRISNAWATI, H.; KALLIO, M.; KANNINEM, M. Acacia mangium Willd.: Ecology, silviculture and productivity. Bogor: CIFOR, 2011. 15p.

KURINOBU, S.; ARISMAN, H.; HARDIYANTO, E.; MIYAURA, T. Growth model for predicting stand development of Acacia mangium in South Sumatra, Indonesia, using the reciprocal equation of size-density effect. Forest Ecology and Management, v.228, p.91-97, 2006. DOI: 10.1016/j.foreco.2006.01.049.

LACLAU, J.-P.; BOULIETT, J.-P; GONÇALVES, J.L.M.; SILVA, E.V.; JOURDAN, C.; CUNHA, M.C.S.; MOREIRA, M.R.; SANTANDRÉ, L.; MAQUÈRE, V.; NOUVELLON, Y.; RANGER, J. Mixed-species plantations of Acacia mangium and Eucalyptus grandis in Brazil. 1. Growth dynamics and aboveground net primary production. Forest Ecology and Management, v.255, p.3905-3917, 2008. DOI: 10.1016/j.foreco.2007.10.049.

LIMA, R. Crescimento, biomassa e carbono de Pinus taeda L. em função do espaço vital. 2014. 104p. Tese (Doutorado) Universidade Federal do Paraná, Curitiba.

MEAD, D.J.; MILLER, R.R. The establishment and tending of Acacia mangium. ACIAR Proceedings, v.35, p.116-122,1991.

MOREIRA, J.M.M.A.P. Potencial e participação das florestas na matriz energética. Pesquisa Florestal Brasileira, v.31, p.363372, 2011. DOI: 10.4336/2011.pfb.31.68.363.

NIRSATMANTO, A. Early growth of improved Acacia mangium at different planting densities. Journal of Tropical Forest Management, v.22, p.105-113, 2016. DOI: 10.7226/jtfm.22.2.105.

NOUVELLON, Y.; LACLAU, J.-P.; EPRON, D.; LE MAIRE, G.; BONNEFOND, J.-M.; GONÇALVES, J.L.M.; BOUILLET, J.-P. Production and carbon allocation in monocultures and mixedspecies plantations of Eucalyptus grandis and Acacia mangium in Brazil. Tree Physiology, v.32, p.680-695, 2012. DOI: 10.1093/ treephys/tps041.

PEDROSA, T.D.; MASCARENHAS, A.R.P.; MELO, R.R.; STANGERLIN, D.M. Estimativa da biomassa em plantios de Eucalyptus grandis na região Centro-Oeste. Scientia Plena, v.9, p.1-7, 2013.

PEGORARO, R.F.; SILVA, I.R. da; NOVAIS, R.F. de; BARROS, N.F. de; CANTARUTTI, R.B.; FONSECA, S. Estoques de carbono e nitrogênio em Argissolo submetido ao monocultivo de Eucalyptus urograndis e em rotação com Acacia mangium. Ciência Florestal, v.24, p.935-946, 2014. DOI: 10.5902/1980509816607.

PROJETO RADAMBRASIL. Folha NA.20 Boa Vista e parte das folhas NA.21 Tumucumaque, NB.20 Roraima e NB.21: geologia, geomorfologia, pedologia, vegetação e uso potencial da terra. Rio de Janeiro, 1975.426p. (Levantamento de recursos naturais, v.8).

PROTÁSIO, T. de P.; GOULART, S.L.; NEVES, T.A.; TRUGILHO, P.F.; RAMALHO, F.M.G.; QUEIRÓZ, L.M.R. de S.B. Qualidade da madeira e do carvão vegetal oriundos de floresta plantada em
Minas Gerais. Pesquisa Florestal Brasileira, v.34, p.111-123, 2014. DOI: $10.4336 / 2014$.pfb.34.78.657.

QUIRINO, W.F.; VALE, A.T. do; ANDRADE, A.P.A. de; ABREU, V.L.S.; AZEVEDO, A.C. dos S. Poder calorífico da madeira e de materiais ligno-celulósicos. Revista da Madeira, n.89, p.100-106, 2005.

SANTOS, F.M.; BALIEIRO, F. de C.; ATAÍDE, D.H. dos S.; DINIZ, A.R.; CHAER, G.M. Dynamics of aboveground biomass accumulation in monospecific and mixed-species plantations of Eucalyptus and Acacia on a Brazilian sandy soil. Forest Ecology and Management, v.363, p.86-97, 2016. DOI: 10.1016/j. foreco.2015.12.028.

SEREGHETTI, G.C.; LANÇAS, K.P.; SARTORI, M.S.; REZENDE, M.A.; SOLER, R.R. Efeito do espaçamento no crescimento e na densidade da madeira de Eucalyptus urophylla x Eucalyptus grandis em florestas de ciclo curto. Energia na Agricultura, v.30, p.257-262, 2015. DOI: 10.17224/ EnergAgric.2015v30n3p257-262.

SOARES, T.S.; CARNEIRO, A. de C.O.; GONÇALVES, E. de O.; LELLES, J.G. de. Uso da biomassa florestal na geração de energia. Revista Cientifica Eletrônica de Engenharia Florestal, ano 4, 2006. Sem paginação.

SOUZA, C.R. de; ROSSI, L.M.B.; AZEVEDO, C.P. de; LIMA, R.M.B. de. Comportamento da Acacia mangium e de clones de Eucalyptus grandis x E. urophylla em plantios experimentais na Amazônia Central. Scientia Forestalis, v.65, p.95-101, 2004.

TONINI, H. Características em plantio e propriedades da madeira de Acacia mangium. In: TONINI, H.; HALFELD-VIEIRA, B. de A.; SILVA, S.J.R. da (Ed.). Acacia mangium: características e seu cultivo em Roraima. Brasília: Embrapa Informação Tecnológica; Boa Vista: Embrapa Roraima, 2010. p.63-81.

VALE JÚNIOR, J.F. do; SCHAEFER, C.E.G.R. Solos sob savanas de Roraima: gênese, classificação e relações ambientais. Boa Vista: Gráfica Ioris, 2010. 219p.

VALE, A.T. do; BRASIL, M.A.M.; CARVALHO, C.M. de; VEIGA, R.A. de A. Produção de energia do fuste de Eucalyptus grandis Hill ex Maiden e Acacia mangium Willd. em diferentes níveis de adubação. Cerne, v.6, p.83-88, 2000.

VALE, A.T. do; BRASIL, M.A.M.; MARTINS, I.S. Variação axial na densidade básica da madeira de Acacia mangium Willd. aos sete anos de idade. Ciência Florestal, v.9, p.85-92,1999. DOI: 10.5902/19805098386.

VÉLEZ, D.A.T.; DEL VALLE, J.I. Growth and yield modelling of Acacia mangium in Colombia. New Forests, v.34, p.293-305, 2007. DOI: $10.1007 / \mathrm{s} 11056-007-9056-5$.

VITAL, B.R.; ANDRADE, A.M. de; VALENTE, O.F.; CAMPOS, J.C.C. Influência da casca no rendimento e qualidade do carvão vegetal de Eucalyptus grandis. IPEF, n.41/42, p.44-49, 1989.

$\overline{\text { Received on May 10, } 2017 \text { and accepted on October 9, } 2017}$ 